\title{
ACCEPTING TOLERANCE AND DIVERSITY
}

\author{
Madeleine Hoss \\ Metcalf Laboratory School Librarian \\ Illinois State University \\ 216 Concord Drive \\ Normal, IL 61761 USA \\ E-mail: mmhos@rs600.cmp.ilstu.edu.us \\ Roslyn Wylie \\ Teaching Materials Center Librarian \\ Milner Library \\ Illinois State University \\ 1506 Northbrook Drive, \#101 \\ Normal, IL 61761 USA \\ E-mail: roslyn@mhsgate.mlb.ilstu.edu.us
}

\begin{abstract}
Exploring diversity instills in children an awareness and respect for themselves and others. Research projects that address stereotyping, race relations, and prejudice within ourselves can be developed through collaboration between the librarian and classroom teacher (who may themselves be of different cultures). These research projects help children to understand that the world is made up of interrelated people; that people must not be judged on appearance or background alone; and that individuals and their contributions to society are of primary importance. These projects encourage children to be more tolerant of others and to savour the rich diversity of the changing world culture.
\end{abstract}

\section{THE NEED FOR TOLERANCE}

We educators are well aware that multicultural education is already an increasingly important and vital component of our educational environmant. In our multicultural society children are constantly exposed to a global information society. Getting along in a changing world is essential and children must be taught to be more tolerant of others.

They must learn to appreciate the rich diversity of America's changing culture.

When children become more tolerant, their self-confidence is increased. This creates the ability to be comfortable and thus learn to interact in all kinds of situations and mix with all different people. This gift of tolerance is found in our hearts. We cannot buy it at a gift or department store. Tolerance is one way to show acceptance and respect for our differences. It becomes the most precious and important gift of love for all-young or old.

We as educators need to create ways and means to guide our children in this globally perplexing and changing world. We know we are imperfect, but we are assured that global interaction will better children's conflict resolution skills. It will also help to create a more enjoyable and interesting life.

\section{THE ROLE OF READING}

Teaching children to celebrate differences and not discriminate is the solution. We must teach our students that prejudice, hatred, and stereotyping are not acceptable. These are behaviors that can be overcome. When children can appreciate and understand their own origin and heritage will this not lead them to appreciate the traditions, customs and beliefs of others? Through reading and research we can explore with our children the rich and wonderful cultures thriving in America today-cultures 
such as African-American, Arab-American, Japanese-American, Jewish-American, Central American, Chinese-American, Irish-American, Korean-American, Mexican-American, Native American, Puerto Rican-American, and Vietnamese-American. Studying and celebrating differing cultural values, traditions, and family living concepts enriches students with a greater acceptance and understanding of their American heritage and community.

A present and important concern of librarians, public and school, is the promotion of reading. It is the responsibility of every educator to create an atmosphere of reading-a "reading culture." The materials must be well selected in order to attract and entice readers of all kinds. Students will find it harder to resist well selected sources with fascinating photographs and personal narratives such as the You Were There autobiographies. These fresh autobiographies that explore the way people live will acquaint readers with the basics of a culture's history and heritage. Students will become aware that their lives and their own historical era are an intimate part of this on-going human saga. Bringing the world to the library develops in children the appreciation of the contributions and achievements for the global people they encounter.

We educators need to implement diverse ways to promote cultural diversity. Implementing ethnic programs - educational and fun projects - with their activities will make libraries the windows to the world. We must encourage students to pursue reading and guide them to examine their attitudes. Will this not broaden their appreciation of others and raise questions to research their beliefs? We first teach children to be tolerant of one person or one group of persons, then we expand from the small groups to larger groups of people. In this way, we will promote cultural diversity and be able to plant the seed of peace. tolerance.

Truly we must tell our children that racism and prejudice are not acceptable. We must teach

\section{PROJECTS AT ILLINOIS STATE UNIVERSITY}

The Conceptual Frameworks for Teacher Education at Illinois State University includes statements reflecting the moral and intellectual virtues of its graduates. Among the moral and intellectual virtues are these: a sensitivity toward the varieties of individual and cultural diversity; a respect for learners of all ages and a special regard for childhood and adolescence; and a knowledge and appreciation of the diversity among learners. The Teaching Materials Center collections are a reflection of these virtues.

When teacher education students are introduced to the TMC materials and instructed in their use in a classroom setting, they too are inculcated with these virtues and they learn what materials will best produce the desired learning outcomes.

Materials that promote cultural diversity and tolerance in a positive way are available from many publishers and in many formats-book and nonbook. The non-book materials promoting cultural diversity and tolerance can include such items as videotapes, sound cassettes and sound CDs, CD-ROM products, pictures, posters, games, kits, puzzles, models and realia. Below is a bibliography of sources and a list of publishers.

\section{A BIBLIOGRAPHY OF TOLERANCE AND DIVERSITY SOURCES}

\section{Books}

Adamson, L. G. (1994). Recreating the past: A guide to american and world historical fiction for children and young adults. Westport, CT: Greenwood.

Alcoze, T. (1993). Multiculturalism in mathematics, science, and technology:reading and activities. Menlo Park, CA: Addison Wesley.

Anderson, V. (1994). Cultures outside the united states in fiction: A guide to 2,875 books for librarians and teachers, $k-9$. Jefferson, NC: McFarland.

Barker, K. (Ed.). (1992). Information books for children. Brookfield, VT: Ashgate Publishing.

Bielich, P. \& Page, F. (1995). Science cultural crossroads: A bibliography of multicultural science trade books. Detroit: Science Crossroads.

Blake, B. (1995). A guide to children's books about Asian Americans. Brookfield, VT: Scolar Press. Breen, K. (1988). Index to collective biographies for young readers (4th ed.). New York: Bowker. 
Brewer, C. \& Grinde, L. (Eds.). (1995). Many people, many ways: Understanding cultures around the world.Tucson, AZ: Zephyr.

Carey, S. J. (1993). Science for all cultures: A collection of articles from NSTA's journals. Arlington, VA: National Science Teachers Association.

Cultural kaleidoscope: An american alphabet. (1993).Madison, WI: Knowledge Unlimited.

Day, F. A. (1994). Multicultural voices in contemporary literature: A resource for teachers. Portsmouth, NH: Heinemann.

Gath, T. and Sosa, M. (Eds.). (1996). Science books and films' best books for children, 1992-1995. Washington, DC: American Association for the Advancement of Science.

Gordon, L. and Tanaka, C. (1995). World historical fiction guide for young adults. Fort Atkinson, WI: Highsmith.

Hayden, C. D. (Ed.). (1992). Ventures into cultures: a resource book of multicultural materials and programs Chicago: ALA.

Helbig, A. K. and Perkins.A. R. (1994). This land is our land: A guide to multicultural literature for children and young adults. Westport, CT: Greenwood .

Jeness, A. (1993). Come home with me: A multicultural treasure hunt. New York: Norton.

Kennedy, D. M., Spangler, S. S. \& Vanderwerf, M. (1990). Science and technology in fact and fiction: A guide to children's books. New York: Bowker.

Kennedy, D. M., Spangler, S. S. \& Vanderwerf, M. (1990). Science and technology in fact and fiction: A guide to young adult books. New York: Bowker

Knight, M. B. (1992). Talking walls. Boston: Tilbury House

Knight, M.B. (1993). Who belongs here?: An american story. Boston: Tilbury House.

Kuipers, B. J. American indian reference and resource books for children and young adults (2nd ed.). Englewood, CO: Libraries Unlimited, 1995.

McGowan, M. (1994). Appreciating diversity through children's literature: Teaching activities for the primary grades. Englewood, CO: Teachers Ideas Plus.

Manna, A. J. Brodie, C. S. (Eds.). (1992). Many faces, many voices: Multicultural literary experiences for youth. The Virginia Hamilton Conference. Fort Atkinson, WI: Highsmith Press, 1992.

Manthey, C. M. (1995). With respect for others: Activities for a global neighborhood. Atlanta, GA: Humanics Learning.

Miller-Lachman, L. (1995). Global voices, global visions: A core collection of multicultural books. New York: Bowker.

Miller-Lachman, L (1992). Our family, our friends, our world. New York: R.R.Bowker.

Multicultural literature for children and young adults (3rd ed.) (1991). Madison, WI: University of Wisconsin Department of Public Instruction, Cooperative Children's Book Center.

Perl, T. (1993). Women and numbers: Lives of women mathematicians plus discovery activities. San Carlos, CA: Wide World Publishing/Tetra.

Rochman, H. (1993). Against borders: Promoting books for a multicultural world. Chicago: ALA.

Rollock, B. (1992) Black authors and illustrators of children's books (2nd ed.). New York: Garland Publishing.

Schon, I. (1995). A latino heritage, series 5: A guide to juvenile books about latino people and cultures. Lanham, MD: Scarecrow Press.

Science and Environmental Education Unit, California Department of Education. (1993)._Literature for science and mathematics, kindergarten through grade twelve. Sacramento, CA: Science \& Environmental Education Unit, California Department of Education.

Thiessen, D. \& Mattias, M. (Eds.). (1992). Wonderful world of mathematics: A critically annotated list of children's books in mathematics. Reston, VA: National Council of Teachers of Mathematics.

Van Meter, V. (1992). World history for children and young adults: An annotated bibliographic index. Englewood, CO: Libraries Unlimited.

Wade, M. D. (1994). Ada Byron Lovelace: The lady and the computer. New York: Dillon.

\section{Periodicals}

Book Links A Booklist Publication, American Library Association

Cobblestones Cobblestone Publishing

Faces Cobblestone Publishing 
Faces Cobblestone Publishing

Multicultural Review Greenwood Publishing Group

\section{Publishers}

Chelsea Curriculum Publication, School Division P.O.Box 5186

Yeadon, PA 19050-0686

800-362-9786

Children's Book Press

6400 Hollis Street, Suite 4

Emeryville, CA 94608

510-655-3395

Culture Catalog

City Lore

72 E. First Street

New York, NY 10003

800-333-5982

Gryphon House Inc.

P.O. Box 207

Beltsville, MD 20074-0207

800-638-0928

Hampton-Brown Books

P.O. Box 223220

Carmel, CA 93922

800-338-3510
Lerner Group

241 First Avenue North

Minneapolis, MN 55401

800-328-4929

Pocahontas Press, Inc.

P.O. Drawer F

Blacksburg, VA 24063-1020

800-446-0467

Polychrome Publishing

4509 N. Francisco Avenue

Chicago, IL 60625-3808

Shen's Books and Supplies

821 S. First Avenue

Suite A

Arcadia, CA 91006

818-445-6958

Smithsonian/Folkways Recordings

9661 L'Enfant Plaza, Suite 2600

Smithsonian Institution

Washington, DC 20560 